Egyptian Journal of Aquatic Biology \& Fisheries

Zoology Department, Faculty of Science,

Ain Shams University, Cairo, Egypt.

ISSN $1110-6131$

Vol. 23(3): 117 - 125 (2019)

www.ejabf.journals.ekb.eg

\title{
Population Biology and Dynamics of Fringelip Mullet Crenimugil crenilabis, Forsskål, 1775 from Southern Red Sea, Egypt
}

\author{
Manal M. Sabrah*, Azza A. El-Ganainy and Rasha A. Heneish \\ National Institute of Oceanography and Fisheries, NIOF, Egypt \\ *Corresponding Author: manal_sabrah@yahoo.co.uk
}

\section{ARTICLE INFO}

\section{Article History:}

Received: June 16, 2019

Accepted: June 28, 2019

Online: July 1, 2019

\section{Keywords:}

Red Sea

Crenimugil crenilabis

Fringelip Mullet

Commercial fishery

Population Biology

Population Dynamics

\section{ABSTRACT}

This study was conducted to assess the biological characteristics and growth pattern of Crenimugil crenilabis for the first attempt in the Egyptian Red Sea. C. crenilabis is a rewarding fish in the Red Sea small scale fishery. 350 samples were obtained seasonally during the period 2017 to 2018 from the commercial fishery operating in Shalatin, southern Egyptian Red Sea. Total length was varied from 24.0 to $49.4 \mathrm{~cm}(35.0 \mathrm{~cm}$ mean, SD: 4.75$)$ and total weight ranged from 157.0 to $1265.0 \mathrm{~g}$ (476.58 g mean, SD: 214.47). The weight at length relationship showed an isometric growth pattern $(b=3.052)$. The von Bertalanffy growth constants $\mathrm{K}$ and Lo were estimated using ELEFAN I method. The growth parameters were found to be $K=0.36 /$ year and $\mathrm{L} \infty=51.5 \mathrm{~cm}$. The annual total mortality coefficient $(\mathrm{Z})$, natural mortality (M) and fishing mortality (F) were estimated to be $1.26,0.73$ and $0.53 /$ year respectively. The length at first capture $\left(\mathrm{L}_{\mathrm{c}}\right)$ was calculated at $35.65 \mathrm{~cm}$, while the length at first maturity $\left(\mathrm{L}_{\mathrm{m} 50}\right)$ was found to be 32.7 for males and $33.3 \mathrm{~cm}$ for females. The exploitation rate of $C$. crenilabis was determined as 0.42 , indicating the under- exploited level where the maximum exploitation level reported was 0.5 . Thus the study recommended preserving the current level of exploitation rate to conserve the population stock of $C$. crenilabis from the breakdown.

\section{INTRODUCTION}

The Fringelip mullet, Crenimugil crenilabis, locally known as Araby, it is a member of the family Muglidae, it is widely distributed throughout Indo-Pacific: Red Sea and East Africa to the Line and Tuamoto islands, north to southern Japan, south to Lord Howe Island (Lieske and Myers, 1994). C. crenilabis is marine, brackish, schooling and non-migratory species, lives at maximum depth $20 \mathrm{~m}$ at tropical; $32^{\circ} \mathrm{N}$ - $32^{\circ} \mathrm{S}, 32^{\circ} \mathrm{E}-143^{\circ} \mathrm{W}$ (Bacchet et. al., 2006). C. crenilabis reported in coastal waters, over sandy or muddy areas of lagoons and associated to reef flats with maximum length of $60 \mathrm{~cm}$ TL, while the common length observed was $30 \mathrm{~cm}$ TL (Harrison and Senou, 1997).

Very minor knowledge is available on the biological traits of $C$. crenilabis, however (Al-Abdessalaam, 1995 and Randall, 1995), reported its maximum size and studied the feeding behavior in Oman, Arabian Sea. Helfrich and Allen (1975) concluded the reproduction and the spawning time in Micronesian waters. Al-Nahdi et. al., (2008) studied length-weight relationships, maturity, and reproductive time of C. crenilabis from Oman, Arabian Sea Coast. 
C. crenilabis is an abundant species in fish markets of the southern Red Sea from Hurghada to Shalateen with high demand. It is regarding to be commercial species in this region constituting 2\% of the total Red Sea catch (GAFRD, 2016).

Despite the commercial importance of $C$. crenilabis, there was no literature had done in Egypt; this work represents the first attempt to study its population biology in the Egyptian Red Sea.

This context aimed to evaluate the present fishery status of the Red Sea mullet, by the study of size frequency distribution, length at first maturity, length at first capture and the exploitation rates, in order to conserve $C$. crenilabis stock in the Egyptian Red Sea.

\section{MATERIALS AND METHODS}

\section{Data Collection and the study area}

Samples of Crenimugil crenilabis were collected seasonally during 2016 to 2018 from the artisanal commercial boats adopted in El-Shalateen fishing port, southern Red Sea, Egypt. C. crenilabis mainly exploited by artisanal fishery using small fiberglass boats with outboard engines that using trammel and gillnets as well as hand and long line techniques.

Shalateen fishing port is located at $700 \mathrm{~km}$ south Hurghada and at $280 \mathrm{~km}$ southern to Marsa Alam, Egyptian Red Sea. It is located between latitude $23^{\circ} 09 \backslash 0 \backslash \backslash$ $\mathrm{N}$ and longitude $35^{\circ} 36 \backslash 511 \mathrm{E}$ (Fig. 1). Shalateen Coastal area is very wide and shallow, with narrow beach composed of sand. The tidal flat is very wide, extends smoothly with very gentle slope seaward. The bottom of the bay floor is sandy and covered with algal flats and sea grass. Coral reefs are found seaward parallel to the shoreline. The long shore confronting the city is good for fishing industry.
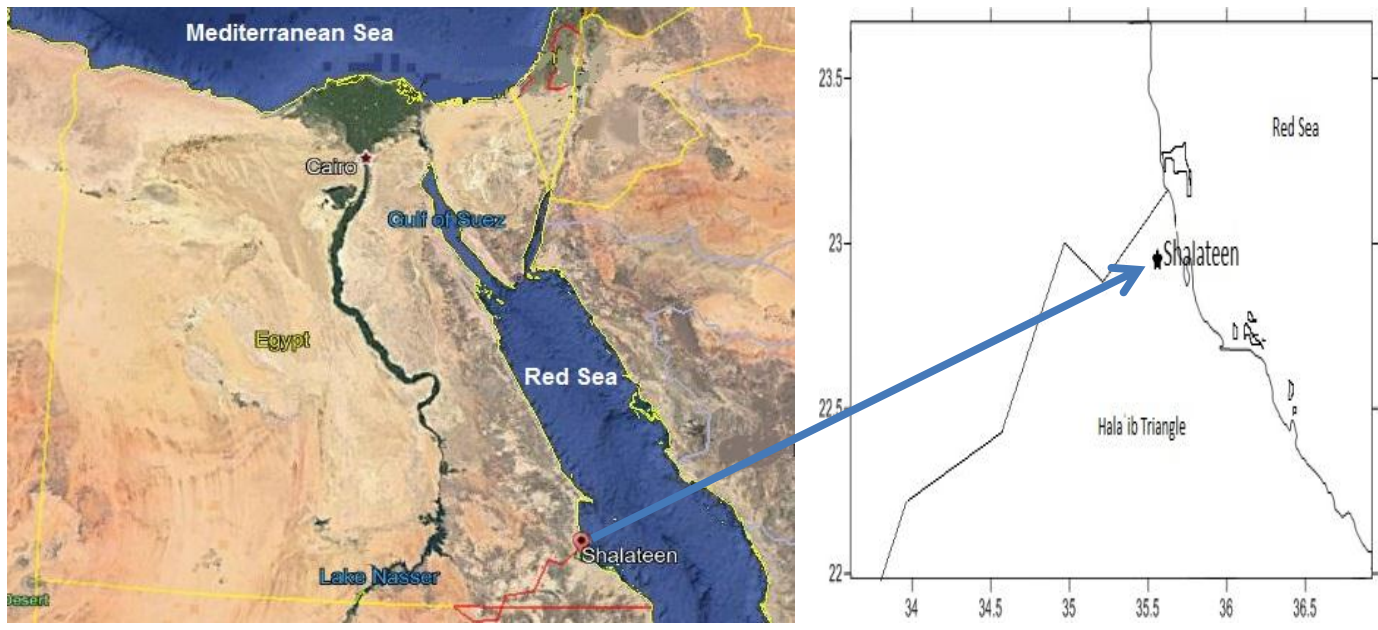

Fig. 1: Demonstrated Shalateen fishing sit, southern Egyptian Red Sea

\section{Data analysis}

Fish total lengths (TL) to the nearest $(\mathrm{mm})$ and fish total weight (TW) to the nearest $(\mathrm{g})$ were measured for 350 fish samples. Samples of $C$. crenilabis were dissected and separated into males and females. Gonads were examined and their weights $(\mathrm{GW})$ were recorded to the nearest $0.01 \mathrm{~g}$. 


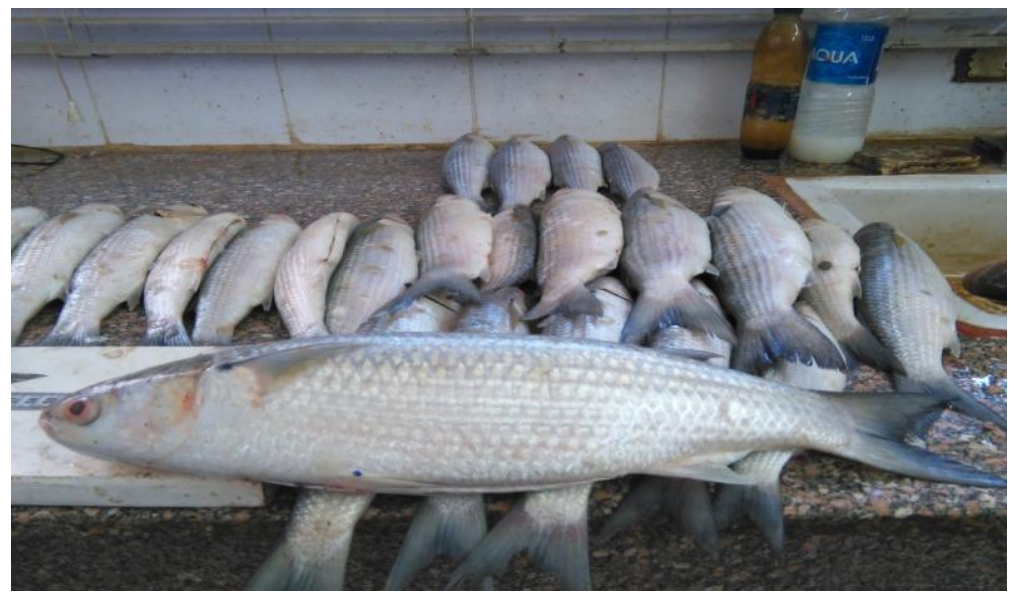

Fig. 2: Crenimugil crenilabis dissected and separated at NIOF, fisheries biology Lab

\section{Length Frequency Distribution:}

The Total length measurement of 350 specimens of C. crenilabis was distributed into length classes of $2 \mathrm{~cm}$ interval. A bar chart was plotted to show the variation of length frequency distribution in males and females.

Weight at length relationship was computed according to (Ricker, 1975) exponential regression equation $\mathrm{TW}=\mathrm{a} \mathrm{TL}^{\mathrm{b}}$ where $\mathrm{a}$ (intercept), $\mathrm{b}$ (slope), TW (total fish weight) and TL (total fish length).

\section{Age and growth studies:}

Sagitta otoliths of 350 fish were cleaned, dried and conserved for the age determination. Otoliths annual rings were counted using stereomicroscope transmitted light. The length-frequency data were used to estimate the Von Bertalanffy, 1938 growth parameters, (Lo) the total asymptotic length and $(\mathrm{K})$, the growth coefficient by using the ELEFAN I incorporated in FiSAT II (FAO ICLARM Stock Assessment Tools) Software (Gayanilo et al., 2005).

\section{Mortality rate estimation:}

FiSAT II software package (Gayanilo et al., 2005), ELEFAN I was used to estimate the total mortality Z/year using the length converted catch curve (Pualy, 1983). $\mathrm{Z}$ was calculated from the slope (-b) with sign changed of the descending right arm of the curve. The natural mortality rate M/year was calculated by Pauly, 1980 empirical equation: $\mathrm{Ln} \mathrm{M}=-0.0152-0.279 \mathrm{Ln} \mathrm{L} \infty+0.6543 \mathrm{Ln} \mathrm{K}+0.463 \mathrm{Ln} \mathrm{T}$. This formula depends on $(\mathrm{T})$ which is related to the annual mean water temperature of the southern Red Sea $\left(24.0{ }^{\circ} \mathrm{C}\right)$. Fishing mortality $\mathrm{F}$ was derived as $\mathrm{F}=\mathrm{Z}-\mathrm{M}$ (Silvestre and Graces, 2004). The exploitation rate (E) was estimated according to (Gulland, 1969) $\mathrm{E}=\mathrm{F} / \mathrm{Z}$.

\section{Probability of capture:}

Probability of capture estimated from the length converted catch curve routine and determined the final $\mathrm{L}_{25}, \mathrm{~L}_{50}$ and $\mathrm{L}_{75}$ (Lengths related to 25, 50 and $75 \%$ of fish would be vulnerable to the gear) (Pauly, 1984).

The size at maturity $\left(\mathbf{L}_{\mathbf{m} 50}\right)$ was computed for both sexes by analyzing the maturation curve between mature and immature fish at $5 \mathrm{~cm}$ interval. The mean size at maturity was estimated as the size at which $50 \%$ of samples were mature and $50 \%$ were immature (Pitt, 1970).

Relative yield-per-recruit and relative biomass-per-recruit:

The Relative Yield per-Recruit ( $\left.\mathrm{Y}^{\prime} / \mathrm{R}\right)$ was computed using model of Beverton \& Holt (1964) as modified by Pauly and Soriano (1986) and incorporated in the FiSAT software. $E_{\max }, E_{0.1}$ and $E_{0.5}$ values were computed by using the program, 
where, $E_{\max }$ is the maximum sustainable exploitation rate, $E_{0.1}$ is the exploitation rate at which the marginal increases of relative yield/recruit tend to be $1 / 10$ th and $E_{0.5}$ is the exploitation rate under which the stock has been reduced to $50 \%$ of its unexploited biomass. Relative biomass/recruit $\mathrm{B}^{\prime} / \mathrm{R}$ was estimated from the relationship $\mathrm{B}^{\prime} / \mathrm{R}=\left(\mathrm{Y}^{\prime} / \mathrm{R}\right) / \mathrm{F}$.

\section{RESULTS AND DISCUSSION}

\section{The length-frequency distribution}

350 samples of Crenimugil crenilabis were sorted with total length ranged from 24.0 to $49.0 \mathrm{~cm}$. There were 226 females $(64.6 \%)$ and 124 males $(35.4 \%)$. Females TL ranged from 24.0 to $49.5 \mathrm{~cm}$ and males TL from 24.0 to $42.6 \mathrm{~cm}$ (Fig. 3). It is observed that females can grow longer than males and constituted about two third of the total samples. Data revealed that males were dominated in small lengths and exhibited approximately identical value with females at length groups from 24.0 to $33.9 \mathrm{~cm}$. It is clear from (Fig. 3) that the length groups $32.0-35.9 \mathrm{~cm}$ were considered to be the most abundant length groups constituting about $38 \%$ of the total samples.

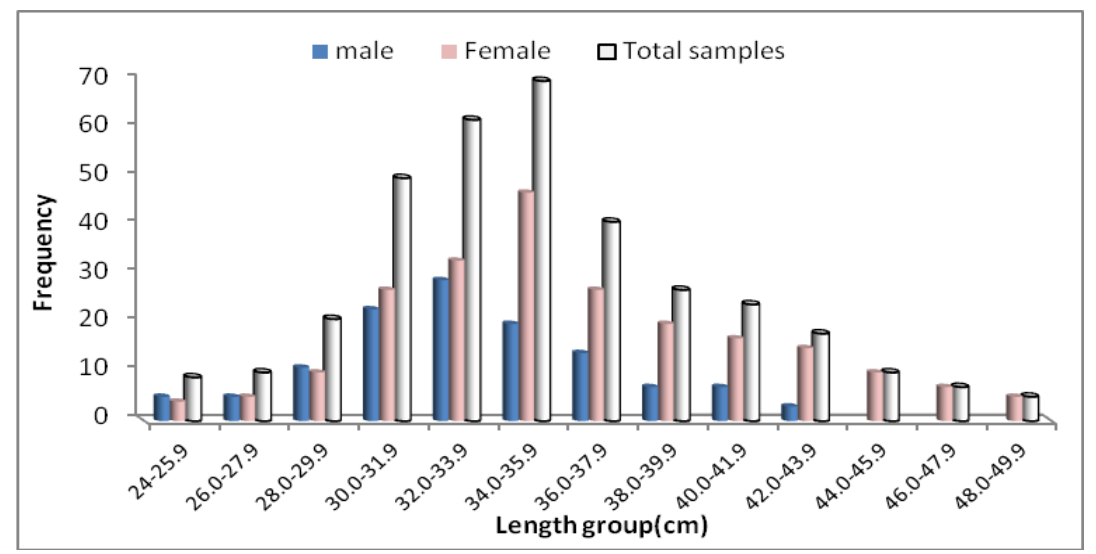

Fig. 3: Length frequency distribution of C. crenilabis from Shalateen, Southern Red Sea

There are no previous studies dealing the population length structure of $C$. crenilabis from Shalateen, Southern Red Sea, Egypt.

Availability of food, spawning rates, breeding grounds, current and depth of water have been suggested as major factors affecting the distribution and abundance of various fish families. Factors affecting fish distribution and abundance have been reported by Olatunde, (1977) and Lelek \& El-Zarka, (1993). Allison et al., (1997), reported also that fish distribution and abundance may be varied with gear type used, time of capture and the seasonally condition. In the present study the observed results revealed that the fishing pressure depending on the lengths of 32.0 and $35.0 \mathrm{~cm}$ by about $38 \%$ of the total catch. Also it was noticed that adult fish exhibited small values (Fig. 3); this may be attributed to fishers targeting large sizes in order to maintain high production (Ama-Abasi et al., 2004). Al-Nahdi et al., (2008) concurrence with our results, where they concluded that females dominated samples of $C$. crenilabis than males in Oman, Arabian Sea.

\section{Weight at Length relationship}

The relationship between total weight and total length of $C$. crenilabis is presented in (Fig. 4). The analysis of variance (t-Test) revealed there is no significant difference between males and females ( $p>0.05$ ). The minimum and maximum total length varied between 24.6 and 49.4 with an average of $35 \pm 4.75 \mathrm{~cm}$, and those of 
weight from 157.0 to 1265.0 with a mean of $476.58 \pm 214.47 \mathrm{~g}$. The Results showed that, the slope $(b=3.052)$ was not significantly different from 3.0 (t-Test, $P>0.05)$, indicating the isometric growth pattern of C. crenilabis.

These results exhibit differences when compared (a) and (b) values determined by other authors for the same species, where in Philippines water Gumanao et al., (2016) revealed that the length varied from 11.5 to $42.5 \mathrm{~cm} \mathrm{SL}$ and $\mathrm{a}=0.037, \mathrm{~b}=2.86$. In Oman, Al-Nahdi et al., (2008) concluded that the size varied between 12.0 and $54.5 \mathrm{~cm}$ TL with mean size of $32.4 \mathrm{~cm}$ and $a=0.0225 \& \mathrm{~b}=2.769$. The (b) value could be an indicator of the physiological condition of the fish and vary seasonally in response to seasonal variations in environmental condition and changes in the fish wellbeing (Biswas, 1993).

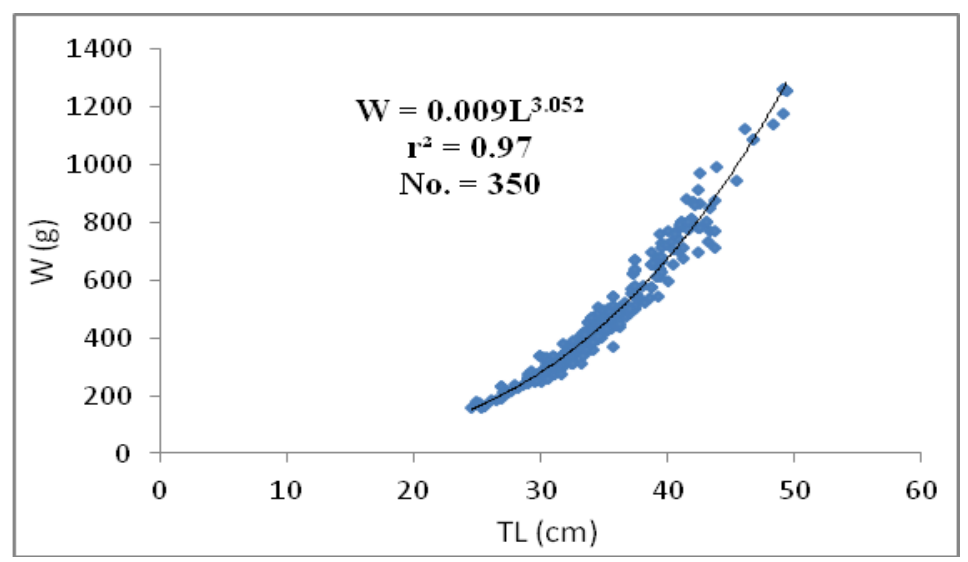

Fig. 4: Weight at Length relationship of C. crenilabis from Shalateen, Southern Red Sea

\section{Age determination}

Age determination is considered to be one of the most important bases to study the fish stock assessment. Otoliths believe among the best hard fish structures used in the age determination.

350 otoliths were used for the age determination of $C$. crenilabis collected from Shalatin fishing port at the southern Egyptian Red Sea. Otoliths reading exhibited five age groups; the mean lengths at age were 26.7, 33.0, 39.7, 44.1 and $47.5 \mathrm{~cm}$ for age groups I, II, III, IV and V respectively (table 1). The results revealed that the maximum growth rates was detected at the first year of life, then a gradual decrease was observed as the fish increase in age. It is observed that age group III was the most frequent one constitutes $37.1 \%$.

Table 1: Mean length at each age group, growth increment and age composition $\%$ of C. crenilabis from Shalateen, Southern Red Sea, Egypt.

\begin{tabular}{ccccc}
\hline Age group (year) & Fish No. & $\begin{array}{l}\text { Mean lengths }(\mathrm{cm}) \\
\text { at each age group }\end{array}$ & Increment $(\mathrm{cm})$ & $\begin{array}{c}\text { \%of age } \\
\text { composition }\end{array}$ \\
\hline I & 45 & 26.7 & 26.7 & 12.9 \\
II & 75 & 33.0 & 6.3 & 21.4 \\
III & 130 & 39.7 & 5.7 & 37.1 \\
IV & 80 & 44.1 & 4.9 & 22.9 \\
V & 20 & 47.5 & 3.5 & 5.7 \\
\hline
\end{tabular}

\section{Growth parameters}

The von Bertalanffy growth parameters of $C$. crenilabis were estimated at $\mathrm{L} \infty=$ $51.5 \mathrm{~cm}$ and $\mathrm{K}=0.36 \mathrm{yr}^{-1}$. These values did not show much difference when compared to the $\mathrm{L} \infty$ and $\mathrm{K}$ values estimated by the other authors for the same genus, 
where Venkatesha et al., (2003), studied the age and growth of Crenimugil sahli from India and concluded $\mathrm{L} \infty=53.4 \mathrm{~cm}$ and $\mathrm{K}=0.285 /$ year.

Stergiou (2000) explained the importance of the proportion of fish maximum length $\left(\mathrm{L}_{\max }\right)$ to the asymptotic length $(\mathrm{L} \infty)$ in the fish life history, as he reported that the value of $\mathrm{L}_{\max } / \mathrm{L} \infty$ for marine fish ranged between 0.56 and 1.34. In the present work the maximum length observed to be $\mathrm{L}_{\max }=49.0 \mathrm{~cm}$, so the value of $\mathrm{L}_{\max } / \mathrm{L}_{\infty}$ was found to be 0.95 which is very close to Stergiou (2000) suggestion for 383 marine fish.

\section{Annual Mortality and exploitation rates}

The estimated annual mortality rates $\mathrm{Z}, \mathrm{M}$ and $\mathrm{F}$ were found to be $1.26 / \mathrm{yr}$, $0.73 / \mathrm{yr}$ and $0.53 / \mathrm{yr}$ respectively. (Fig. 5) represents the catch curve apply the estimation of $\mathrm{Z}, \mathrm{M}, \mathrm{F}$ and $\mathrm{E}$ which corresponding to the exploitation rate $(\mathrm{E}=0.42)$, which is nearly in the optimum range according to Patterson (1992). According to Etim et al., 1999, who reported that if $\mathrm{Z} / \mathrm{K}$ ratio $\approx 2$ in case Powell-Wetheral plot, that is indicate the overexploitation. In the present work, the $\mathrm{Z} / \mathrm{K}$ ratio was found to be 0.75 which confirmed the under-exploitation ratio of $C$. crenilabis. According to Gulland (1971) suggestion who stated that the stock is optimized when F=M. The current study revealed that $\mathrm{F}<\mathrm{M}$ by about $27 \%$, so the stock is generally in the optimum exploited state.

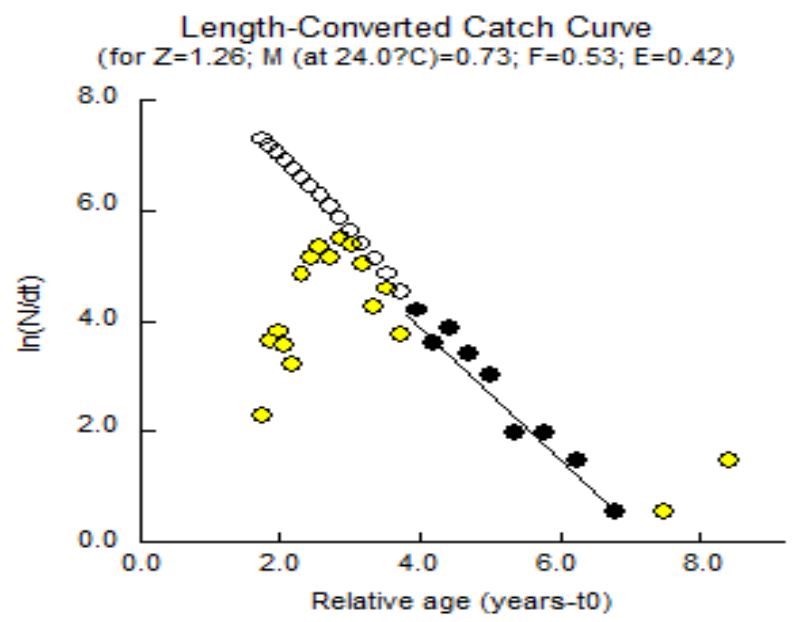

Fig. 5: Length converted catch curve of C. crenilabis from Shalateen, Southern Red Sea (indicating Z, $\mathrm{M}, \mathrm{F}$ and $\mathrm{E}$ )

\section{Probability of capture and size at first maturity}

The estimated sizes for $25 \%\left(\mathrm{~L}_{25}\right), 50 \%\left(\mathrm{~L}_{50}\right)$ and $75 \%\left(\mathrm{~L}_{75}\right)$ probabilities of capture would be $32.65,35.63$ and $38.60 \mathrm{~cm}$, respectively for C. crenilabis (Fig. 6). The length at first capture $\mathrm{L}_{c 50}$ was found to be $35.63 \mathrm{~cm}$. It is well known that $\mathrm{L}_{\mathrm{c}}$ is related to the net mesh size. Fig. (7), shows the mean size at first sexual maturity $\mathrm{L}_{\mathrm{m} 50}$ which estimated to be $32.7 \pm 1.55 \mathrm{~cm}$ for males and $33.3 \pm 1.65 \mathrm{~cm}$ for females. It is clear that length at maturity for $C$. crenilabis $\left(\mathrm{L}_{\mathrm{m} 50} \approx 33.0 \mathrm{~cm}\right)$ is smaller than the length at capture $\left(\mathrm{L}_{\mathrm{c} 50}=35.63\right)$, this means that, the present level of $\mathrm{L}_{\mathrm{c}}$ is suitable length at first capture for $C$. crenilabis from the coastal area of Shalateen. 


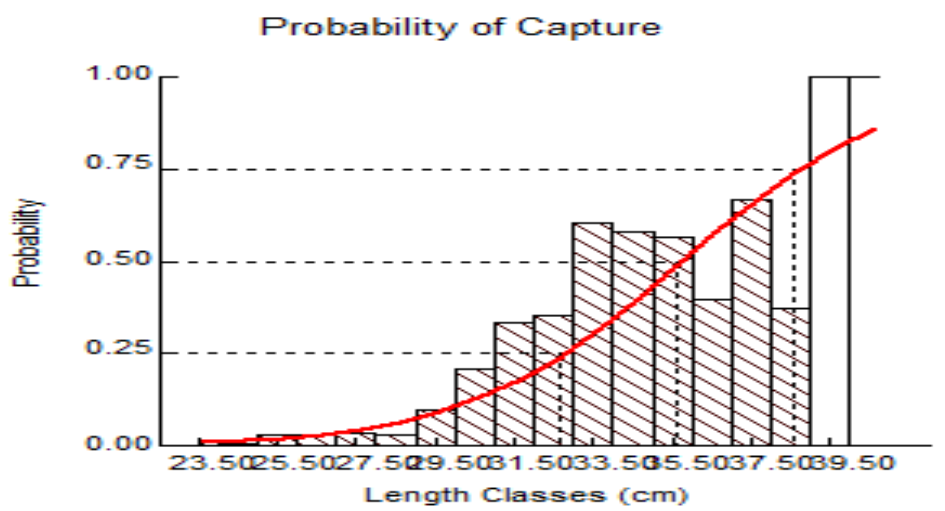

Fig. 6: Probability of capture of each length class of C. crenilabis $\left(\mathrm{L}_{25}=32.65 \mathrm{~cm}, \mathrm{~L}_{50}=35.63 \mathrm{~cm}, \mathrm{~L}_{75}\right.$ $=38.60 \mathrm{~cm}$ )

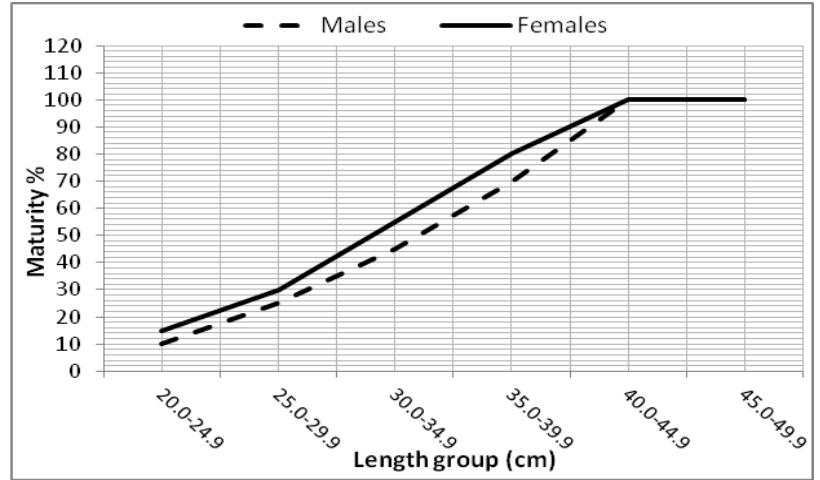

Fig. 7: Size at first maturity of C. crenilabis from Shalateen, Southern Red Sea

\section{Relative yield-per-recruit and relative biomass-per-recruit}

Beverton and Holt (1964), relative yield per recruit estimated using the knifeedge method is given in Fig. 8, the optimum exploitation rates were estimated as; $\mathrm{E}_{\max }=0.421, \mathrm{E}_{10}=0.355$ and $\mathrm{E}_{50}=0.421$. The computed exploitation ratio was 0.42 , which is equal to the predicted maximum exploitation rate $\left(\mathrm{E}_{\max }\right)$ of 0.421 , which further lend credence to the fact that $C$. crenilabis is in the optimum fishing situation

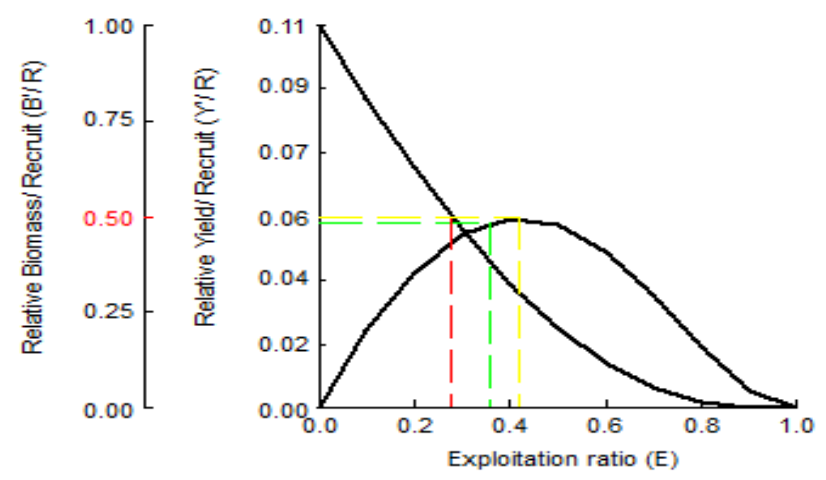

Fig. 8: Relative yield-per-recruit and relative biomass-per recruit of $C$. crenilabis using the knife-edge $\operatorname{method}\left(\mathrm{E}_{0.1}=0.355, \mathrm{E}_{0.5}=0.278\right.$ and $\left.\mathrm{E}_{\max }=0.421\right)$.

The yield contours predict the response of relative yield-per-recruit of the fish to changes in $\mathrm{L}_{\mathrm{c}}$ (length at first capture) and $\mathrm{E}$ (exploitation rate); $L \mathrm{c} / L \infty=0.05$. $L c / L \infty$ values represent different scenarios equivalent to changes in mesh size. E corresponds to changing levels of $F / Z$. 


\section{CONCLUSION}

In conclusion, evidence abound that $C$. crenilabis is in the optimum exploitation rate in the Southern Red Sea, Egypt and the current fishing level is in the suitable manner. Urgent caution needs to fix the current fishing effort to conserve the optimum yield and protect the fish stock through the concerted communities and government agencies.

\section{REFERENCES}

Al-Abdessalaam, T.Z.S. (1995). Marine Species of the Sultanate of Oman: An Identification Guide. Ministry of Agriculture and Fisheries, Marine Science and Fisheries Centre, Sultanate of Oman. Muscat Printing Press, 412 pp.

Allison, M.E.; Gabriel, U.U.; Inko-Tariah, M.B.; Davies, O.A and Udeme Naa, B. (1997). The Fish Assemblage of Elechi Creek, Rivers State, Nigeria. Niger Delta Biologia, 2: 59-73.

Al-Nahdi, A.; Al-Marzouqi, A. and Al-Shajibi, S. (2008). Length-Weight Relationships, Maturity, and Reproductive Season of the Fringelip Mullet Crenimugil crenilabis (Forsskål, 1775) from the Arabian Sea Coast of Oman. Agricultural and Marine Sciences, 13:23-32.

Ama-Abasi, D.; Holzloehner, S. and U. Enin. (2004). The dynamics of the exploited population of Ethmalosa fimbriata (Bowdich, 1825, Clupeidae) in the Cross River Estuary and adjacent Gulf of Guinea. Fish. Res., 68: 225-235.

Bacchet, P.; Zysman, T. and Lefèvre, Y. (2006): Guide des poissons de Tahiti et ses îles. Tahiti (Polynésie Francaise): Editions Au Vent des Îles. 608 pp.

Bertalanffy, L.V. (1983). A quantitative theory of organic growth. Human Biology 10:181213.

Beverton, R. J. H. and Holt, S. J. (1964). Tables of yield functions for fishery assessment. FAO, Fish. Tech. Pap. No. (38). Rome, Italy.

Biswas, S.P. (1993). Manual of methods in fish biology. South Asia, New Delhi, India.

Etim, L.; P.E. Lebo and R.P. King. (1999). The dynamics of an exploited population of a Siluroid catfish (Schilbe intermidius, Reupell 1832) in the Cross River, Nigeria.Fish. Res., 40: 295-307.

GAFRD, (2016). Statistical Book of General Authority for Fish Resources Development, Egypt.

Gayanilo, F.C.; Sparre, P. and Pauly, D. (2005). FAO-ICLARM Stock Assessment Tools II(FiSAT II), User's Guide, Computerized Information Series (Fisheries) No. 8, (Revised Version), FAO, Rome, Italy.

Gulland, J. A. (1969). Manual of methods for fish stock assessment. Part1. Fish population. FAO Manuals in Fisheries Science, No. 4, 154 pp.

Gulland, J. A. (1971). The fish resources of the Oceans. West Byfleet Survey, Fishing News (Books) Ltd, For FAO. 255 pp.

Gumanao, G.S.; Saceda-Cardoza, M.M.; Mueller, B. and. Bos, A.R (2016). Length-weight and length-length relationships of 139 Indo-Pacific fish species (Teleostei) from the Davao Gulf, Philippines. J. App. Ichthyol. 332:377-385.

Harrison, I.J. and Senou, H. (1997). Order Mugiliformes. Mugilidae. Mullets. p. 2069-2108. In K.E. Carpenter and V.H. Niem (eds.) FAO species identification guide for fishery purposes. The living marine resources of the Western Central Pacific. Volume 4. Bony fishes part 2 (Mugilidae to Carangidae). FAO, Rome.

Helfrich, P. and Allen, P.M. (1975). Observations on the spawning of mullet, Crenimugil crenilabis (Forskal), at Enewetak, Marshall Islands. Micronesia, 11:219-225.

Lelek, A. and El-Zarka, S. (1993). Ecological Comparison of the Preimpounded Fish Faunas of the Niger and Kainji Lake, Nigeria, Geophys. Monogaph, 17: 655-660. 
Lieske, E. and Myers, R. (1994). Collins Pocket Guide. Coral reef fishes. Indo-Pacific \& Caribbean including the Red Sea. Haper Collins Publishers, 400 pp.

Olatunde, A.A. (1977). The Distribution, Abundance and Trends in the Establishment of the Family Schilbeidae (Osteicthyes: Siluriformes) in Lake Kainji, Nigeria. Hydrobiologia, 56, 69-80. https://doi.org/10.1007/BF00023287

Patterson, K. (1992). Fisheries for small pelagic species: an empirical approach to management targets. Rev. Fish Biol. Fish., 2: 321-338.

Pauly, D. (1980). On the interrelationship between natural mortality, growth parameters and mean environmental temperature in 175 fish stocks. Journal of the CIEM 39: 175-192.

Pauly, D. (1983): Some simple methods for the assessment of tropical fish stocks. FAO Fish Tech. Pap. 234:52.

Pauly, D. (1984): Fish population dynamics in tropical waters: A manual for use with programmable calculators. ICLARM Stud. Rev. 8: 325.

Pauly, D. and Soriano, M.L. (1986). Some practical extension to the Beverton and Holt's relative yield-per-recruit model, p. 491-496. In J.L. MacLean, L.B. Dizon \& L.V. Hosillo. The First Asian Fisheries Forum. Asian Fisheries Society, Manila, Philippines.

Pitt, T. K. (1970). Distribution, abundance and spawning of yellow tail flounder in the new foundland area of the North West Atlantic. J. Fish. Res. Bd. Can., 12: 2261-2271

Randall, J.E. (1995). Coastal Fishes of Oman. Crawford House Publishing Pty Ltd, Bathurst, New South Wales, Australia. 439pp.

Ricker, W.E. (1975). Computation and interpretation of biological statistics of fish population. Bull. Fish. Res. Bd. Can., No. (191), 382 pp.

Silvestre, G.T. and Garces, L.R. (2004): Population parameters and exploitation rate of demersal fishes in Brunei Darussalam. Fish Research, 69: 73-90.

Stergiou, K. I. (2000). Life-history patterns of fishes in the Hellenic Seas. Web Ecology, 1: 110.

Venkatesha Moorthy, K.S.; Reddy, H.R.V. and Annappaswamy, T.S. (2003). Age and growth of blue spot mullet, Valamugil seheli (Forskal) from Mangalore. Indian J. Fish. 50(1):73-79.

ARABIC SUMMARY

بيولوجيه وديناميكيه عشائر أسماك البورى (Crenimugil crenilabis) من جنوب البحر الأحمر، مصر

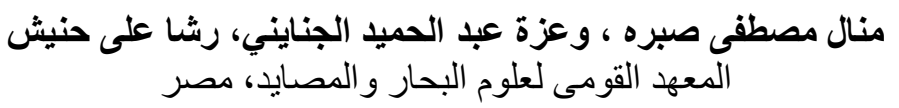

تهدف هذه الدراسة الى تقييم الخصائص البيولوجية ونمط نمو أسماك البورى (Crenimugil crenilabis)

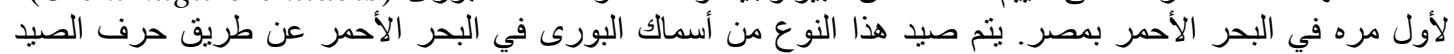

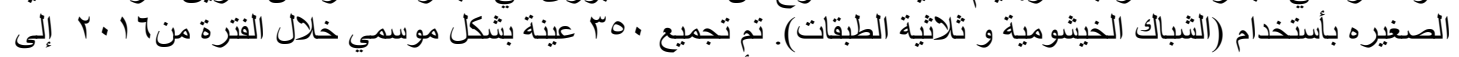

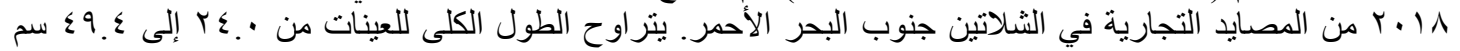

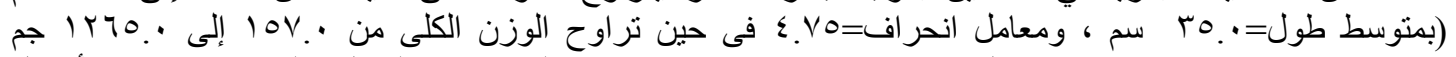

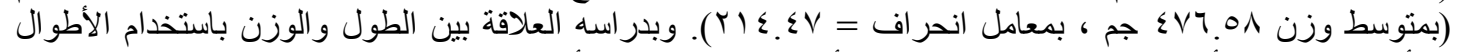

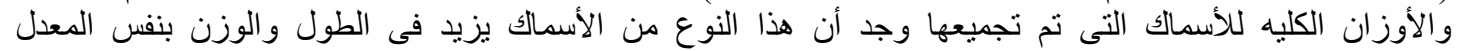
(isometric growth pattern)

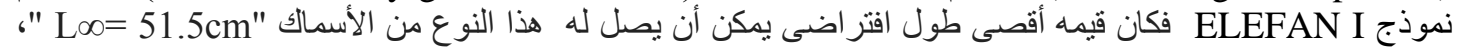

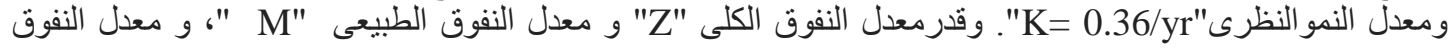

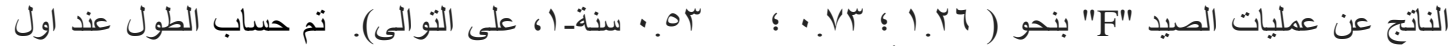

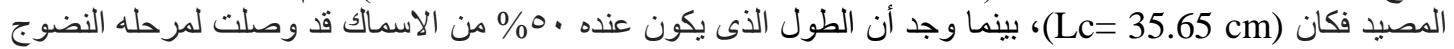

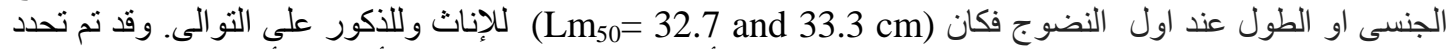

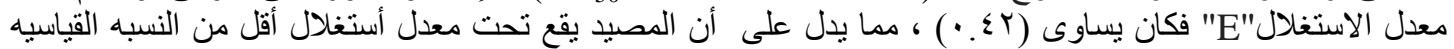

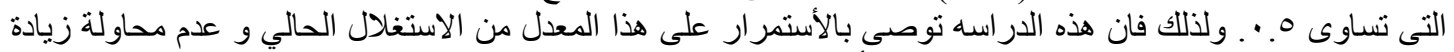
مجهود الصيد الحالى للحفاظ على مخزون مصيد أسماك البورى من الانهيار. 